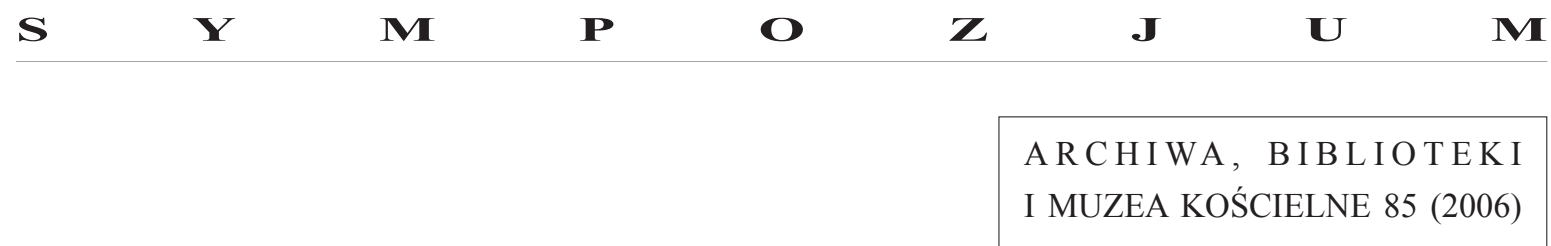

KS. MAREK T. ZAHAJKIEWICZ - LUBLIN

\title{
RELACJA MIEDZY KOŚCIOŁEM A KULTURĄ. WPROWADZENIE DO SYMPOZJUM
}

Zagadnienie relacji między Kościołem a kulturą wymaga głębszej i obszerniejszej refleksji przekraczającej ramy niniejszego wystąpienia. Ponadto wymaga to wieloaspektowego spojrzenia szeregu osób kompetentnych; zarówno teologów, jak i znawców kultury szeroko pojętej. Dla przykładu można przytoczyć obrady Kongresu Teologów Polskich odbytego w Lublinie prawie ćwierć wieku temu, kiedy to kilkudziesięciu prelegentów zastanawiało się na sesjach plenarnych i na posiedzeniach sekcyjnych nad sprawą relacji między chrześcijaństwem a kulturą polską ${ }^{1}$. Biorąc więc pod uwagę te zastrzeżenia musimy zaznaczyć, że obecnie chcemy postawić tylko sam problem relacji między Kościołem a kulturą. Będzie to w pewnym sensie naszkicowanie tła dalszych naszych wspólnych rozważań skupiających się już tylko wokół szczegółowego tematu dotyczącego polskich muzeów kościelnych.

W naszych wystąpieniach poświęconych muzeom obracać się będziemy zasadniczo w kręgu zagadnień kultury, lub z nią związanych. Na skutek tego można postawić sobie pytanie odnośnie do pojęcia kultury. Innymi słowy jak pojmować kulturę?

Kultura jest czymś wieloskładnikowym i wieloaspektowym. Dlatego może istnieje sporo różnych definicji kultury. Najprościej będzie sięgnąć do Encyklopedii katolickiej ${ }^{2}$ i w oparciu o zamieszczone tam hasła podać określenie kultury. Przez to pojęcie należy rozumieć całokształt materialnego (cywilizacja) i duchowego dorobku ludzkości. Kultura jest wynikiem twórczej działalności człowieka. Jest to również zespół wartości, norm i zasad obowiązujących w danej społeczności. Błędne pojmowanie kultury jest wtedy, kiedy zamiennie używa się określenie kultura z pojęciem cywilizacja. Czasami nawet słowo kultura jest używane w opozycji do cywilizacji. Te dwa pojęcia dopełniają się i uzupełnia-

${ }^{1}$ Chrześcijaństwo a kultura polska. V Kongres Teologów Polskich, Lublin 14-16 IX 1983, red. M. Jaworski, A. Skubiś, Lublin 1988.

${ }^{2}$ Encyklopedia katolicka, t. 10, kol. 188. 
ją. Znowu w oparciu o Encyklopedię katolicka ${ }^{3}$ należy przez cywilizację rozumieć rozwój społeczeństwa osiągnięty na pewnym etapie w zakresie środków i zdolności produkcyjnych, oraz instytucji społecznych. Również dochodzi tutaj rozwój w zakresie kultury materialnej. Natomiast zakres pojęcia „kultura” obejmuje równocześnie naukę, sztukę, filozofię, moralność, tradycję itp. Kultury nie można ograniczać np. tylko do piśmiennictwa, poezji itd. Obejmuje ona w pewnym sensie trzy sfery, które są ściśle ze sobą zjednoczone i tworzą na skutek tego pewną całość.

1. Sfera pierwsza to kultura duchowa i ona jest wiodąca.

2. Druga sfera to cywilizacja, czyli to, co kształtuje życie społeczno-prawne i obyczajowe.

3. Wreszcie całość życia materialnego składa się na trzecią sferę.

Po rozpatrzeniu pojęcia samej kultury należałoby zastanowić się nad relacją między Kościołem a kulturą. W stawianiu tego problemu musimy opierać się na oficjalnych dokumentach Kościoła i wypowiedziach papieży. Będą to dokumenty II Soboru Watykańskiego, a głównie Konstytucja duszpasterska o Kościele $w$ świecie współczesnym «Guadium et spes». Również pewne myśli są zawarte w Deklaracji o wychowaniu chrześcijańskim «Gravissimum educationis» i w Dekrecie o działalności misyjnej Kościota «Ad gentes divinitus». W dokumentach soborowych Kościół przedstawiony jest jako instytucja przedłużająca działalność Chrystusa. W tym miejscu rodzi się również pytanie - gdzie i jakie jest tutaj miejsce dla kultury? Sporo materiału na interesujące nas zagadnienie obok dokumentów soborowych dostarczają: Katechizm Kościoła Katolickiego z 1992 r. i wypowiedzi papieży z okresu posoborowego (Paweł VI, Jan Paweł II). Szczególnie Konstytucja duszpasterska wyraźnie mówi o pomaganiu sobie wzajemnym przez Kościół i kulturę. Kościół potrafi nawiązać łączność z różnymi formami kultury, przez co bogaci się zarówno sam Kościół jak i różne kultury. Istnieje również ścisłe a zarazem wielorakie powiązanie pomiędzy głoszeniem „dobrej nowiny” a kulturą. Między innymi Vaticanum II stwierdza: „Pomiędzy orędziem zbawienia a kulturą ludzką istnieją wielorakie powiązania. Bóg bowiem objawia się ludowi swemu aż do pełnego okazania się w Synu Wcielonym, przemawiał stosownie do stanu kultury właściwego różnym epokom"4. Relacja pomiędzy Kościołem a kulturą uwidacznia się szczególnie w celebracji liturgii, która powinna odpowiadać kulturze poszczególnych narodów. Katechizm Kościoła Katolickiego mówi nawet dość dobitnie, by nie niszczyć poszczególnych kultur, ale je należy przenikać i wykorzystać. Zresztą podobne myśli znajdziemy w dokumentach soborowych czy wypowiedziach pap. Jana Pawła II $^{5}$. W tym miejscu warto przytoczyć wspomniany Katechizm z 1992 r.: „Celebracja liturgii powinna więc odpowiadać charakterowi i kulturze różnych narodów. Aby misterium Chrystusa było wszystkim narodom obwieszczone dla skłonienia

\footnotetext{
${ }^{3}$ Tamże, t. 3, kol. 741-742.

${ }^{4}$ Konstytucja «Gaudium et spes», p. 58.

${ }^{5}$ Konstytucja «Sacrosanctum Concilium», p. 37-40; Jan Paweł II, Adhortacja apostolska «Catechesi Tradendae» z 16 X 1979, p. 53.
} 
ich do posłuszeństwa wierze, powinno być głoszone, celebrowane i przeżywane we wszystkich kulturach tak, by nie niszczyło tych kultur, lecz służyło ich odkupieniu i dopełnieniu. Wiele dzieci Bożych właśnie ze swoją kulturą ludzką, przyjętą i przemienioną przez Chrystusa i za jej pośrednictwem ma przystęp do

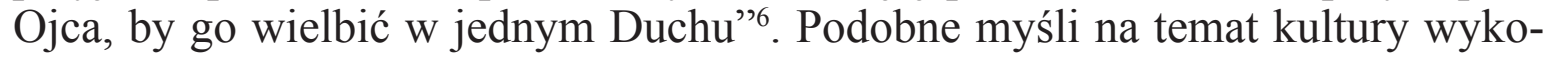
rzystywanej w celebracji liturgicznej znajdujemy również w innym miejscu $\mathrm{Ka}$ techizmu. Ponadto jest tam dodane, ze bazując na odmiennych kulturach powały różne tradycje liturgiczne. Katechizm używa w tym względzie takich słów: „Kościoły tego samego obszaru geograficznego i kulturowego zaczęły celebrować misterium Chrystusa stosując szczególne formy wyrazu typowe dla danej kultury: w tradycji depozytu wiary, w symbolice liturgicznej, w organizowaniu wspólnoty braterskiej, w teologicznym rozumieniu misteriów i różnych formach świętości. W taki sposób Chrystus, Światło i Zbawienie wszystkich narodów, w życiu liturgicznym Kościoła ukazuje się ludowi i kulturze, do których ten Kościół został posłany i w których się zakorzenił. Kościół jest powszechny; może zintegrować w swojej jedności wszystkie prawdziwe bogactwa kultur dokonując ich oczyszczenia" . W powyższej wypowiedzi Katechizm opierał się na dokumentach soborowych i pap. Pawła VI ${ }^{8}$. W dokumentach Kościoła mówi się o wcielaniu Ewangelii w kultury poszczególnych narodów. Mianowicie Katechizm z 1992 r. mówiąc o wypełnianiu zadania misyjnego przez Kościół i o zakładaniu Kościołów lokalnych zaznacza, że ta instytucja „rozwija proces inkulturacji, aby wcielać Ewangelię w kultury narodów"9. Sprawę te poruszył również pap. Jan Paweł II 7 XII 1990 r. w encyklice Redemptoris missio (p. 50). Dokumenty kościelne widzą dla świeckich miejsce w misji Kościoła, w kształtowaniu kultury. Jest o tym mowa w dokumentach soborowych i w Katechizmie ${ }^{10}$. Ten ostatni wspomina, że świeccy powinni „Uzdrawiać istniejące na świecie urządzenia i warunki”. Dalej Katechizm dodaje: „Tak postępując przepoją kulturę i dzieła ludzkie wartością moralną". Jedna kultura łączącą poszczególne ziemie jest równocześnie między innymi czynnikami, podstawą do tworzenia prowincji kościelnych nawet patriarchatów. Katechizm (nr 887) stwierdza: „Kościoły partykularne sąsiadujące ze sobą oraz posiadające jednorodną kulturę tworzą prowincje kościelne lub większe jednostki nazywane patriarchatami lub regionami".

Pap. Paweł VI w swym przemówieniu na zakończenie II okresu Soboru Watykańskiego II oświadczył, że liturgia w hierarchii wartości i godności zajmuje w Kościele pierwsze miejsce ${ }^{11}$. W związku z tym poruszając temat relacji Kościoła do kultury sięgnęliśmy głównie do tekstów z tego zakresu działalności kościelnej. One dobitnie dają świadectwo podejścia Kościoła do kultury, której wyznacza się w tej instytucji należne miejsce.

\footnotetext{
${ }^{6}$ Katechizm Kościoła Katolickiego (z 1992 r.), nr 1204.

${ }^{7}$ Tamże, nr 1202.

${ }^{8}$ Konstytucja «Lumen gentium», p. 23; pap. Paweł VI, Adhortacja apostolska «Ewangelii nuntiandi» z 8 XII 1975, 63-64.

${ }^{9}$ Katechizm, nr 854.

${ }^{10}$ Konstytucja ,Lumen gentium», p. 36; Katechizm, nr 908.

${ }^{11}$ L'Osservatore Romano z. 5 XII 1963.
} 
Na tle dotychczasowych rozważań o kulturze i o relacji Kościoła do niej należy spojrzeć na muzea kościelne. Są to bowiem instytucje kulturalne powiązane równocześnie $\mathrm{z}$ działalnością Kościoła, a w tym nawet $\mathrm{z}$ duszpasterstwem. Ich funkcjonowanie i powiązanie z Kościołem określają słowa pochodzące od Papieskiej Komisji ds. Kościelnych Dóbr Kultury. Mianowicie 21 IX 2001 r przewodniczący Komisji Papieskiej abp Francesco Marchisano przekazując list okólny wspomnianej komisji, a poświecony muzeom kościelnym, skierował pismo do bpa Jana Śrutwy jako do przewodniczącego Rady Episkopatu Polski ds. Kultury i Dziedzictwa Kulturalnego. Umieścił w nim zdanie określające cele i funkcjonowanie muzeów kościelnych pisząc: „Nasza Komisja Papieska, wierna zasadom, które zobowiązała się realizować od początku swej działalności, prezentuje muzea kościelne nie tylko jako miejsce jedynie dla przechowywania dziedzictwa artystycznego, chociaż ta funkcja jest pierwszorzędna, ale także jako właściwe miejsce dla promocji kultury i dla aktywności katechetycznej”. Natomiast sam list okólny zawiera m.in. takie zdanie: „(...) muzeum kościelne, we wszystkich przejawach, jest wewnętrznie związane z życiem Kościoła, ponieważ w sposób widzialny dokumentuje drogę, jaką Kościół przeszedł na przestrzeni wieków gdy chodzi o kult, katechezę, o kulturę i o miłosierdzie. Muzeum kościelne jest więc miejscem, które oprócz geniuszu ludzkiego dokumentuje rozwój życia kulturalnego i religijnego i w ten sposób chroni teraźniejszości”. Nieco dalej znajdujemy następujące zdanie: „(...) muzeum kościelne może stać się głównym punktem odniesienia wokół którego stanie się możliwe przeszłości i odkrycie teraźniejszości w jej najlepszych aspektach, jakże często nieznanych”. A później, że „,...) muzeum jawi się jako miejsce formacji ludzkiej i ewangelizacji chrześcijańskiej na określonym terytorium" 12 . Te słowa dobitnie mówią o muzeum jako o typowej placówce kulturalnej, ale równocześnie głęboko zakorzenionej w działalność duszpasterską Kościoła.

Nasze spotkanie pracowników muzeów kościelnych w Lublinie w dniach 26-27 września 2005 r. zawierało trzy bloki referatów grupujących się wokół zagadnień:

1. Historia polskich muzeów kościelnych i ich podstawy prawne.

2. Działalność muzeów kościelnych (gromadzenie zbiorów, inwentaryzacja, konserwacja itd.).

3. Funkcja kulturalna muzeów kościelnych.

Hasło przewodnie spotkania było następujące: Muzea kościelne w 100-lecie działalności. Samo określenie „w 100-lecie działalności” muzeów nie jest precyzyjne. Niektóre bowiem z tego typu placówek są już po 100-letniej rocznicy powstania, inne do niej się zbliżają a jeszcze inne zaczynają dopiero swoją egzystencję.

${ }^{12}$ Cytuję za „Muzeum Diecezjalne w Zamościu. Biuletyn Muzeum Diecezjalnego”, 4 (20002001) s. 5-7. 